\title{
New Concept of Silica Source in Agates (Fluoride Model)
}

\author{
N E Savva* \\ North-East Interdisciplinary Scientific Research Institute n. a. N. A. Shilo, Russian Academy of Sciences, Russia
}

Submission: April 01, 2021; Published: April 20, 2021

*Corresponding author: N E Savva, Doctor of Geological and Mineralogical Sciences, North-East Interdisciplinary Scientific Research Institute n. a. N. A. Shilo, Far East Branch, Russian Academy of Sciences, Russia

Abstract

The concept is based on the idea of partial dissolution of silicate minerals in the rocks of volcanic flows when interacting with hydrogen fluorine. $\mathrm{HF}$ is the only solvent of silicates. As a result of this interaction, $\mathrm{SiF}_{4}$ gas is formed, filling the bubbles in the boiling lava. The entry of meteor water into the gas cavities leads to the hydrolysis of silicon tetrafluoride to form orthosilicic acid $\left(\mathrm{H}_{4} \mathrm{Si}_{4}\right)$, which is subject to gelation and polymerization. This leads to the formation of silicon dioxide gels, which are necessary for the structure of chalcedony. Thus, chalcedony is formed inside cavities filled with $\mathrm{SiF}_{4}$ gas, and only vadose water enters the cavities through the channels; otherwise, the channels can quickly become clogged with a viscous gel. It is shown that the thickness of the bands in agates depends on the rate of water entry into the gas voids. The slower the $\mathrm{H}_{2} \mathrm{O}$ droplets arrive, the thinner the layers (bands) in the agate. After the fluorine is depleted, the true solutions fall into the cavities, forming crystalline quartz.

Keywords: Agate; Chalcedony; Fluoride formation agates

\section{Introduction}

Chalcedony fills cavities in both acidic and basic igneous rock, seams and voids in intrusive and metamorphic rocks, and replaces previous minerals in sedimentary rocks. This variety of growth conditions almost does not limit its paragenesis. Therefore, there are different models of natural formation and experiments on the synthesis of chalcedony have been successful in many different ways [1-6]. The idea of developing a fluoride model is largely related to the works of I A Bekbulativa [7], which dealt with the methods of industrial synthesis of chalcedony.

\section{Preparing the Cameras}

The formation of natural agates in most cases is associated with volcanic activity. Gas-rich boiling lava contains many gas bubbles, like boiling water. Hot gases come from great depths under high pressure and move upward, as evidenced by their many kilometers of emissions from the volcanic vent. The formation of chambers with an increase in their volume occurs against the background of adiabatic expansion of gases in boiling lava bubbles in a viscous, not cooled environment of magmatic flows. The expansion of the gases causes pressure on the walls of the chambers with an increase in volume, and often the merging of bubbles, that is, the chambers are being prepared for future agates.
As we ascend to the surface, the size of the chambers increases, which is well illustrated by the documentation of the outcrop in the steep wall of the Olsky basalt plateau (Figure 1).

It is this pressure, which spreads evenly throughout the entire volume of the chambers, that regulates (holds at an early stage) the deposition of chalcedony, and then the growth of quartz on the walls of the chambers from the periphery to the center. In the future, when the pressure on the walls ceases, the incoming solutions, already under the influence of gravity, will successively fill the cavity with horizontal layers, forming onyx with a typical striped texture (Figure 2).

On agate sections, channels of subsequent gas and water phase flows into the chambers (geodes) are often found on the successful cut (Figure 3).

\section{The Role of Fluorine in the Formation of Agates}

Analysis of the available literature shows that fluorine is actively released during volcanic eruptions. This is confirmed by the findings of hyeratite- $\mathrm{K}_{2} \mathrm{SiF}_{6}$, which was first found in the products of basalt volcanic eruptions. Potassium fluorosilicate (hieratite-) was first found among the products of the solfataric activity of the volcano La Fossa on the Vulcano Island off the coast 
of Italy. The mineral got its name in honor of the ancient name of this island-Hiera (Hiera). Hyeratite is also found in posteruptive products of Kamchatka volcanoes. It was first mentioned by B I
Piip [8] when describing the eruptions of 1944-1945. It was found in the products of the Great Fissure Tolbachinsky eruption BTTI fumarole fields $[9,10]$.

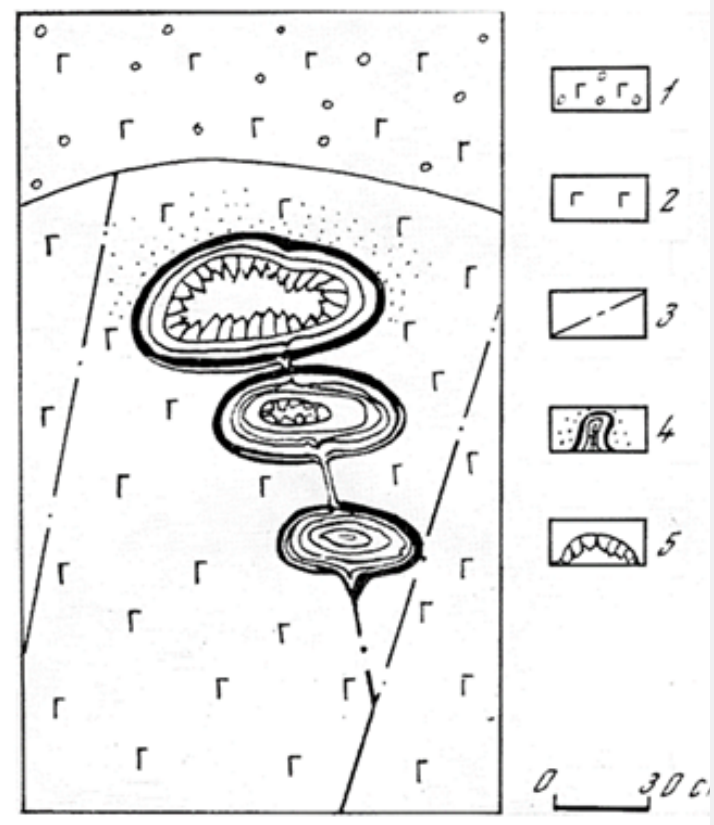

Figure 1: Adiabatic expansion of the chambers as the gas flow rises, and the deposition of chalcedony from silica gels on the walls of the chambers (agate sections show channels-ways of penetration and subsequent inflow of the gas and water phase into the chambers, as well as incomplete filling of the upper chamber):

1-porous basalts; 2-basalts; 3-tectonic cracks; 4-banded chalcedony; 5-drusoid quartz.

Sketch of E V Gunchenko from a field book, 1985 year.

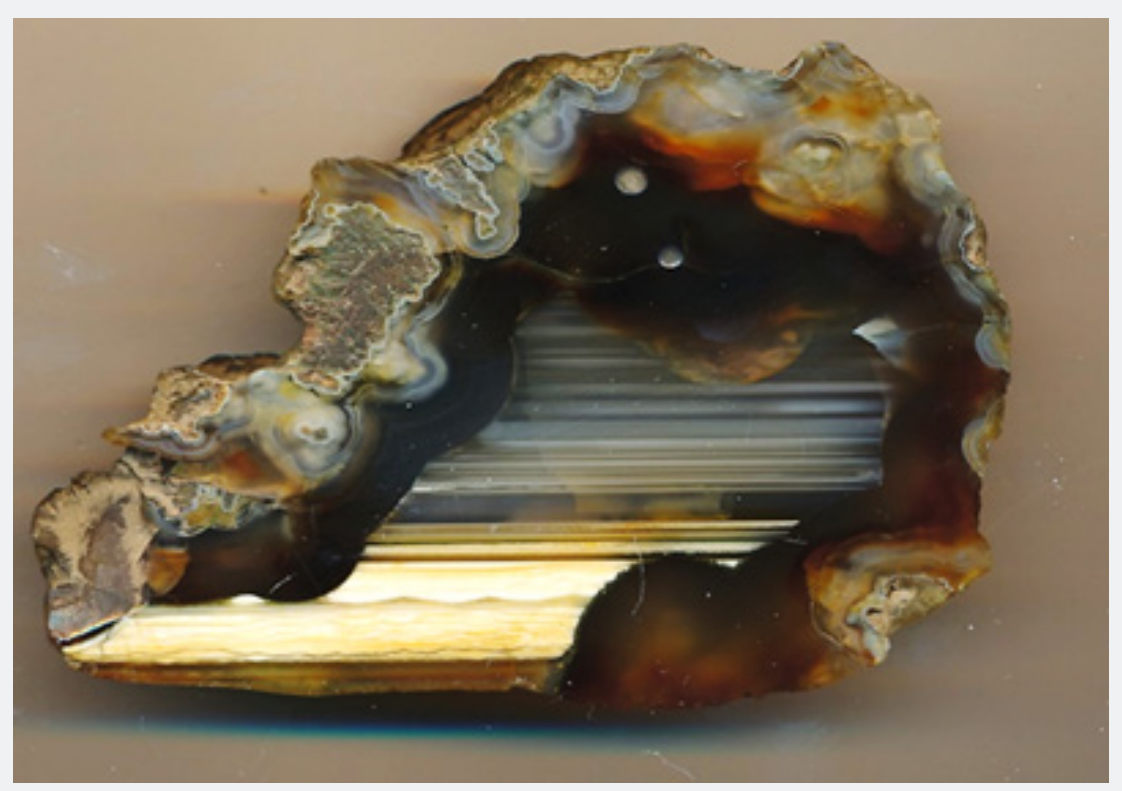

Figure 2: Combination of banded agate covering the chamber walls with banded onyx. Sededema agate deposit. 


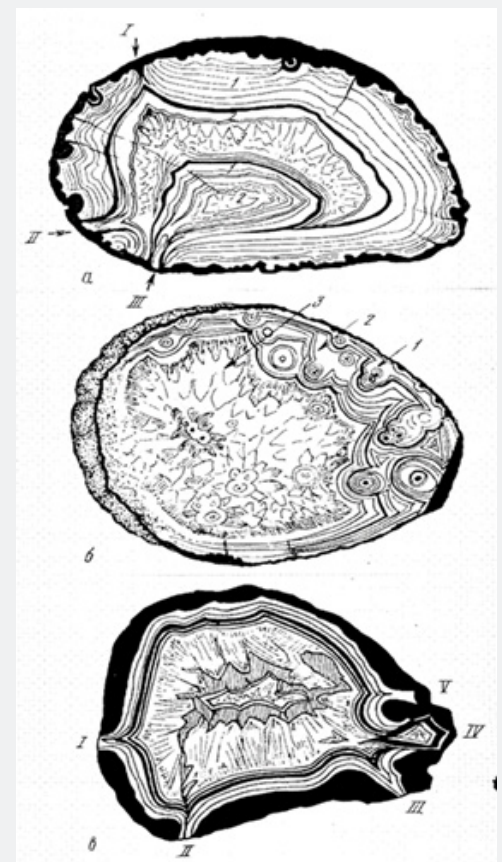

Figure 3: The sequence of gel deposition and true solutions in agate cavities.

a - channels of stepwise flow of colloidal and true solutions:

I - channel of flow of gel forming microrhythms of the first stage;

II - the channel of receipt of gel and true solutions of the second stage;

III -the channel of receipt of gel and true solutions of the third stage;

b-early (1) and late (2) microrhythms of gel deposition; (3)-filling of the center of the geode with a true hydrothermal solution forming a crustifying quartz;

b-channels:

I-III-incoming solutions,

IV - V-outflow of solutions,

I, III - formation of microrhythms of the first stage,

II-formation of microrhythms of the second stage; the center is shaded with carbona.

(Drawing by the author).

Sublimate fluorides often form fluorine-metasomatites, which are depleted of aluminum, sodium and magnesium and enriched with calcium. Sometimes ralstonite $-\mathrm{Na}_{0.5}(\mathrm{Al}, \mathrm{Mg})_{2}(\mathrm{~F}, \mathrm{OH})_{6} \cdot \mathrm{H}_{2} \mathrm{O}$ is found in volcanic rocks, which also confirms the presence of fluorine in volcanic exhalations. Observations in areas of volcanism show that the gas condensates released from magma, lavas, and fumaroles not only dissolve in the reservoir waters, giving them an acidic reaction near the magmatic bodies, but also seep through the fracture zones in the rocks and through the cinder cones [9], Figure 4.

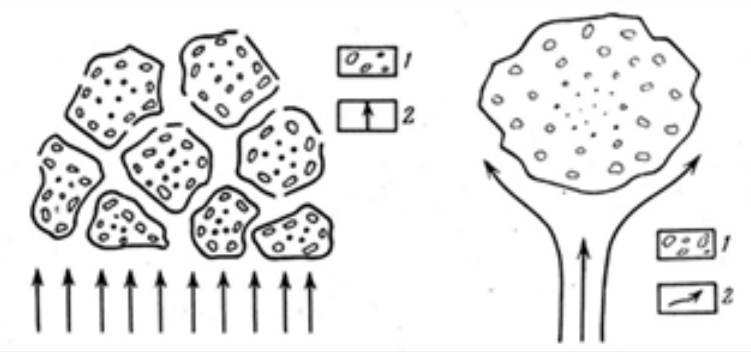

Figure 4: Gas seepage through basalt slag and gas flow around a block of porous basalt (1-slag; 2-gas). Drawings by $S$ I Naboko, Glavatskikh 1983. 
Geologists often ask the question: why in basaltic lavas that do not contain minerals of the $\mathrm{SiO}_{2}$ group, large, often numerous tonsils are formed, filled with agate, the bulk of which is $\mathrm{SiO}_{2}$ ? It seems that the presence of $\mathrm{F}$ in volcanic emanations is of great importance for the formation of silicon oxides in agates. According to L. A. Basharina (1961), 100g of fresh ash from Bezymyanny volcano (Kamchatka) contains easily soluble forms (in $\mathrm{mg}$ ): chlorine 76-530, fluorine 1.5-6.7, sulfur tetrachloride 237-938, carbonic acid 12-104, boric acid 1.5-4.2.

$\mathrm{F}$ - gas in a volcanic explosion reacts with hydrogen over a wide temperature range to form HF:

$$
\mathrm{H}_{2}+\mathrm{F}_{2} \rightarrow 4 \mathrm{HF}
$$

$\mathrm{HF}$ - is the only solvent of silicates, which are mainly composed of volcanic rocks. The heated $4 \mathrm{HF}$, moving up through the pore space and channels, dissolves Si-containing minerals (silicates) on its way, and combines with silicon to form a gaseous silicon tetrafluoride:

$$
40-100^{\circ} \mathrm{C} \rightarrow \mathrm{Si}+4 \mathrm{HF} \rightarrow \mathrm{SiF}_{4}+2 \mathrm{H}_{2}
$$

The gaseous tetrafluoride that fills the chambers (voids in volcanogenic rocks) is hydrolyzed by water to form orthosilicic acid $\left(\mathrm{H}_{4} \mathrm{SiO}_{4}\right)$, and the products formed in this process depend on temperature:

$$
\begin{aligned}
& \mathrm{SiF}_{4}+4 \mathrm{H}_{2} \mathrm{O} \rightarrow \mathrm{H}_{4} \mathrm{SiO}_{4}+4 \mathrm{HF} \\
& 100^{\circ} \mathrm{C} \rightarrow 3 \mathrm{SiF}_{4}+2 \mathrm{H}_{2} \mathrm{O} \rightarrow \mathrm{SiO}_{2}+2 \mathrm{H}_{2}\left[\mathrm{SiF}_{6}\right] \\
& >100^{\circ} \mathrm{C} \rightarrow \mathrm{SiF}_{4}+2 \mathrm{H}_{2} \mathrm{O} \rightarrow \mathrm{SiO}_{2}+4 \mathrm{HF}
\end{aligned}
$$

High-temperature volcanic gases that are released during the introduction of a magmatic body are magmatic emanations. and analogues of hydrothermal fluids (hydrotherms).

As can be seen from the formulas shown, the seepage of $\mathrm{H}_{2} \mathrm{O}$ (VAD, surface water) leads to the dilution of HF, as well as the possible precipitation of silica gels into the sediment with the formation of orthosilicic acid $\mathrm{H}_{4} \mathrm{SiO}_{4}$. Solutions of ortosilicic acid are unstable in time and easily pass into gels, their great tendency to polymerization with, accompanied by polycondensation is manifested: first, linear, then branched, layered and mixed, and finally - three-dimensional structures are obtained [7]. The formation of gels and their polymerization occurs inside the chambers (bubbles), otherwise the gels could block the channels of $\mathrm{H}_{2} \mathrm{O}$ intake.

Depending on the size of the chambers and the volume of $\mathrm{H}_{2} \mathrm{O}$ intake, some geodes are completely filled with chalcedony, but in the case of slow leakage of $\mathrm{H}_{2} \mathrm{O}$ drops, the spaces adjacent to the walls are gradually filled with layers, since they are held by adiabatic expansion (uniform pressure on the walls of the voids). The smaller the portion of incoming $\mathrm{H}_{2} \mathrm{O}$, the thinner the layers in the growing agate up to the thin - layered - "moire".

After the depletion of colloidal solutions, as the fluorine is consumed, true silicon-containing hydrothermal solutions arrive and the formation and growth of quartz crystals begins on the walls of geodes made of chalcedony. The depletion of true solutions often leads to the fact that an empty space (drusovye) voids remain in the geodes filled with quartz (Figure 5a).

In agates associated with basaltic and andesibasaltic outpourings, in drusic voids on quartz, crystal accretions of minerals of the carbonate group - calcite, aragonite, manganocalcite, and rhodochrosite-are later deposited (Figure 5b).
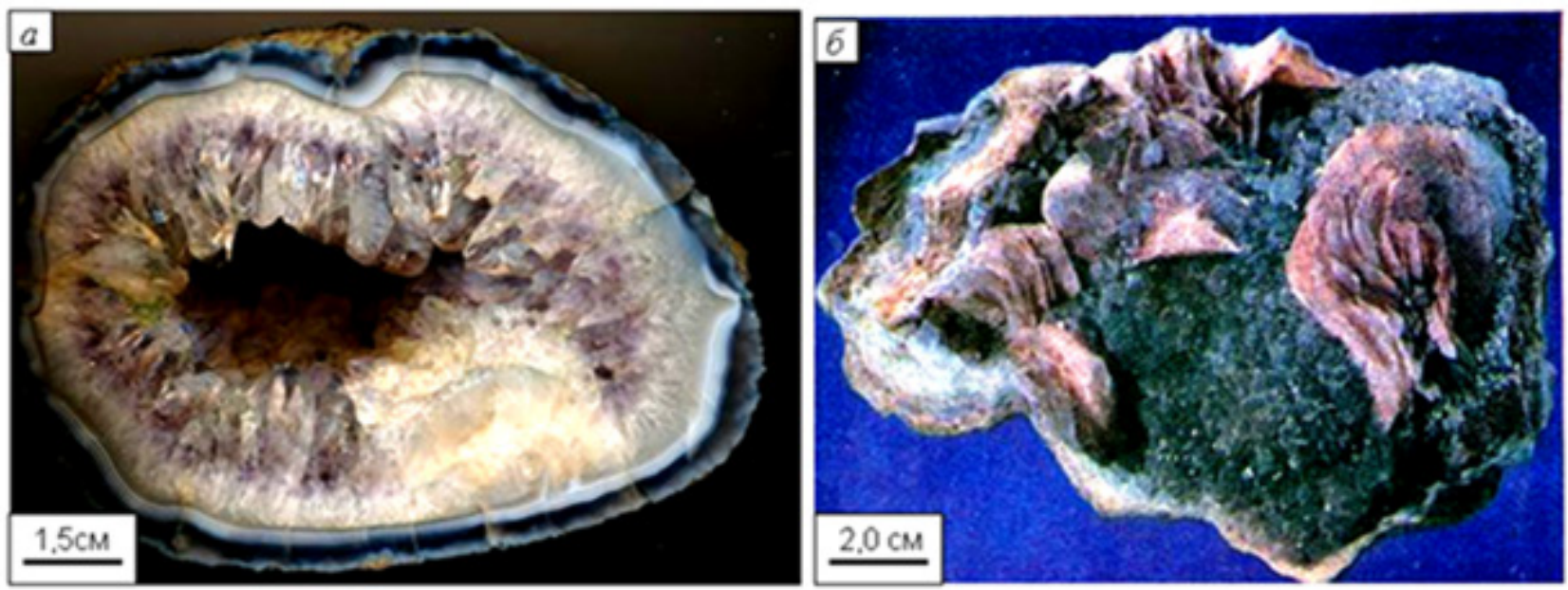

Figure 5: a - in the drusus void-when the solution is insufficient; b - deposition of rhodochrosite on quartz druse (fragment of a large geode); Olskoe plato. 


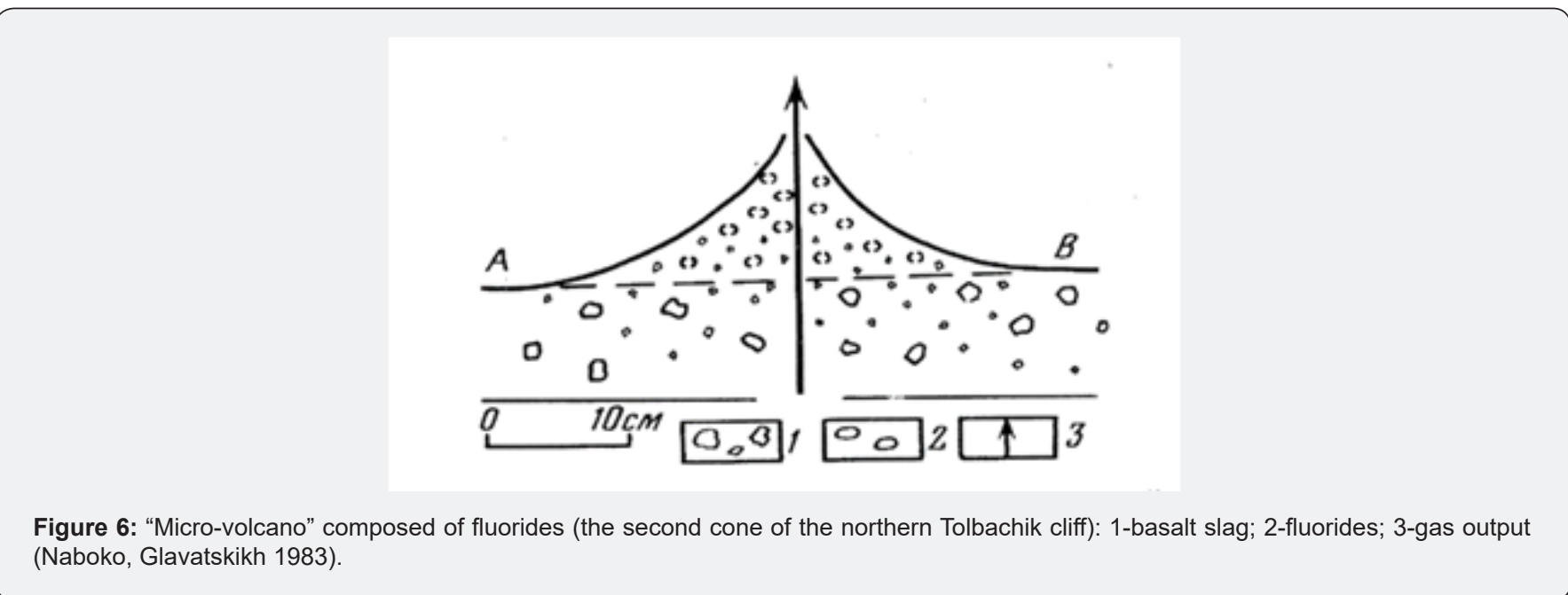

Silicon fluoride reacts with water (hydrolysis) seeping into the gas chamber, and in turn forms a hydrate of silicon oxide silicic acid. As the acidity of the solution decreases, it turns from sol into a gel-like gel. I A Bekbulatova [7] indicates that with strong dilution, the formation of orthosilicic acid $\mathrm{H}_{4} \mathrm{SiO}_{4}$, which exists only in very dilute solutions, is possible. In the processes of fluoride pneumatolysis, water plays an important role, which reacts with volatile compounds. In this case, even quartz can be formed:

$$
\mathrm{SiO}_{2}+\mathrm{SiF}_{4}+2 \mathrm{H}_{2} \mathrm{O}=2 \mathrm{SiO}_{2}+4 \mathrm{HF}
$$

Orthosilicic acid vapors are unstable in time, due to the fact that they are more prone to polymerization, accompanied by polycondensation: first, linear, then branched, layered and mixed, and finally - three-dimensional structures of chalcedony, which are well traced in transmitted light (Figure 6). And here it is important to note that the slower the water seeps, the thinner the layers of chalcedony in the agate. This thinly layered filling gives rise to agates with a "moire" texture (Figure 7a). In turn, the rapid flow of water into the chamber can lead to its complete filling with chalcedony and the absence of stratification in the geode (Figure 7b). The transition of orthosilicic acid to polyacids is accompanied, by the transformation of the molecular solution $\mathrm{H}_{4} \mathrm{SiO}_{4}$ into colloidal solutions - sols. Sols, in turn, either solidify, turning into a gel.
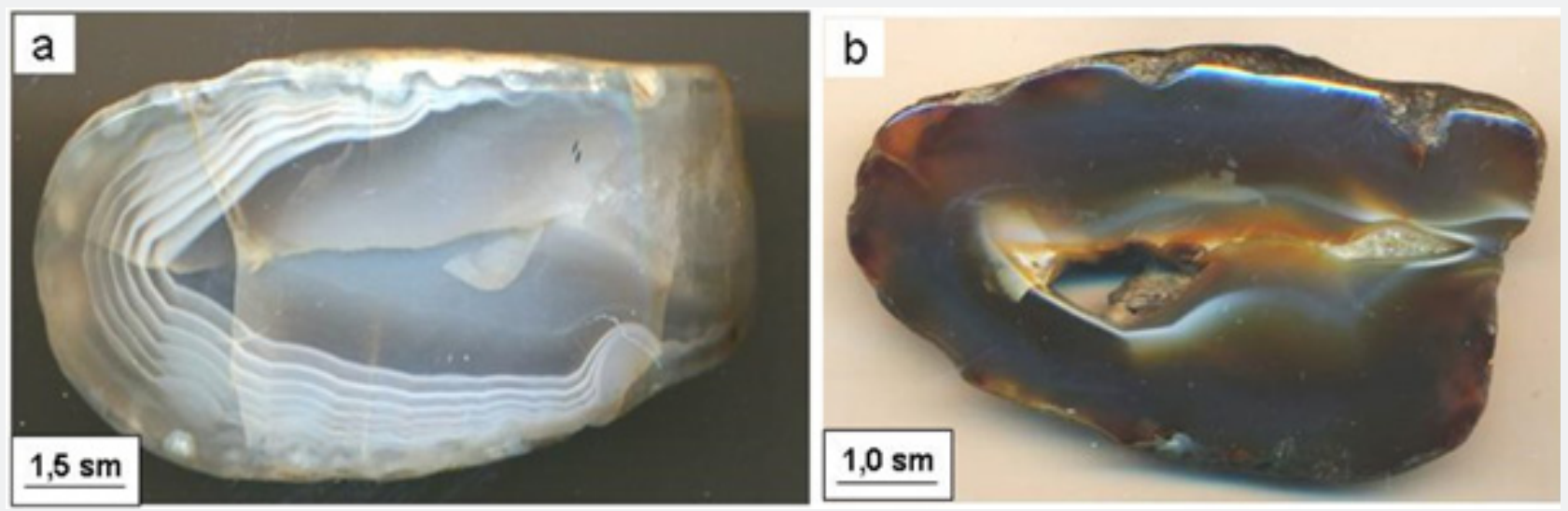

Figure 7: Different filling of the cavity in the agate: a) - the flow of water in small portions-drops, Arman deposit; b) - rapid filling with water through a wide channel-the strips are not formed, Kedon deposit.

Horizontal banded formations (onyxes) inside the geodes indicate the adjustment of the pressure in the chambers and its approach to atmospheric pressure. They fix the deposition of chalcedony under the influence of gravity (gravity). There are options when the pressure adjustment occurs at the stage of colloid intake, and by this time the chambers are already filled. Then crystal quartz is not formed in geodes (Figure 2) [11-14]. 


\section{Conclusion}

The presented fluorinated model perfectly corresponds to natural processes and indicates a very likely source of silica for the formation of agates, even in basaltic lavas. First, the cavities are filled with $\mathrm{SiF}_{4}$ gas, and when the surface waters enter, they form orthosilicic acid, which is prone to conversion into sols and gels, followed by their polymerization. The model can be improved and supplemented with experimental developments and observations of the eruption of modern volcanoes.

\section{References}

1. Godovikov AA, Ripinen OI, Motorin SG (1987) Agaty. Nedra, Moscow. 1967, p. 368.

2. Kigay IN (2019) The Genesis of Agates and Amethyst Geodes. The Canadian Mineralogist 57(6): 867-883.

3. Kigay IN (2017) On the conditions of agate formation. Mineralogy 2 : 75-90.

4. Moxon T (2009) Studies on Agate: Microscopy, Spectroscopy, Growth, High Temperature and Possible Origin. Terra Publications, Doncaster, UK, p. 96.

5. Moxon T, Ríos S (2004) Moganite and water content as a function of age in agate: an XRD and thermogravimetric study. European Journal of Mineralogy 16(2): 269-278.
6. Sedov BM (2019) Verkhne-Olsky agates. - Magadan: The Hunter. p. 244.

7. Bekbulativa IA (2017) Methods of deposition of various silicon compounds from a hydrothermal coolant. Master's degree. Diss 04. 04. 04. Chemistry, Tomsk, p. 58

8. Piip BI (1956) Klyuchevskaya sopka and its eruptions. tr. Lab. Vulkanologii 13: 6-10.

9. Naboko SI, Glavatskikh SF (1992) Posteruptive fluoride mineral formation. Posteruptive mineral formation on active volcanoes of Kamchatka. Vladivostok. Ch. 1, pp. 65-91.

10. Vergasova LP, Filatov SK (1993) Minerals of volcanic exhalations - a special genetic group. ZVMO 1(24): 68-76.

11. Banerjee AK, Laya Mimo MS, Vera Vegas WJ (2001) Silica gel in organic synthesis. Russian Chemical Reviews 70(11): 971-990.

12. Basharova LA (1963) Ekgalyatsii spillover craters of the Klyuchevsky volcano at various stages of lava cooling. In the book. Volcanoes of Kamchatka and some other regions of the USSR. Moscow: Nauka, pp. 169-227.

13. Chan SH (1982) A review on solubility and polymerization of silica. Geothermics 18(1-2): 49-56.

14. Goncharov VI, Gorodinsky ME, Pavlov GF, Savva NE, Fadeev AP, et al. (1987) Halcedones of the North-East of the USSR, p. 192.

Your next submission with Juniper Publishers will reach you the below assets

- Quality Editorial service

- Swift Peer Review

- Reprints availability

- E-prints Service

- Manuscript Podcast for convenient understanding

- Global attainment for your research

- Manuscript accessibility in different formats

( Pdf, E-pub, Full Text, Audio)

- Unceasing customer service

Track the below URL for one-step submission https://juniperpublishers.com/online-submission.php 